UDC 811.163.4'28

https://doi.org/10.18485/bells.2018.10.10

\author{
Andrej Bjelaković* \\ University of Belgrade \\ Faculty of Philology \\ Belgrade, Serbia
}

\title{
WHITHER VARIATIONIST SOCIOLINGUISTICS IN SERBIA?
}

\begin{abstract}
Little has changed since 1965 and Bugarski's original call to study urban speech in Yugoslavia (and his subsequent reporting of new advances regarding the birth of variationist sociolinguistics). We still do not know how the majority of Serbs speak, nor what the scope of stylistic and social variation is in towns and cities of the Serbian-speaking world. This paper will try to show how sociolinguistics in the narrow sense of the term has been largely absent in Serbia; it will try to provide some reasons for this; and it will outline what little has been done in terms of urban dialectology and variationist sociolinguistics.
\end{abstract}

Keywords: sociolinguistics, Serbian, dialectology

\section{Introduction}

First, we will outline the possible meanings of the term sociolinguistics, and then focus on one particular type of sociolinguistics, namely variationist sociolinguistics. We shall then examine whether this discipline has been present at all in the Serbian-speaking world and which attempts got the closest, and try to point out some of the possible reasons for this state of affairs.

E-mail address: b.andrej@sezampro.rs 


\section{The meaning of sociolinguistics}

Sociolinguistics is, famously, a very broad field, and the term is used to cover many disparate ways of studying language (Meyerhoff 2011: 1-2). This is why Trudgill, somewhat tongue in cheek, entitled the introductory chapter to Sociolinguistic Patterns in British English "Sociolinguistics and sociolinguistics" (1978). He divides studies of language and society into three categories: "those where the objectives are purely sociological or socialscientific; those where they are partly sociological and partly linguistic; and those where the objectives are wholly linguistic" (1978:2). The first category is not sociolinguistics, according to Trudgill, while the second category comprises fields such as discourse analysis, ethnography of speaking, anthropological linguistics, sociology of language, social psychology of language, etc. (1978: 4-9). It is the third group that is of interest to us. This is the group Trudgill sometimes refers to as "sociolinguistics proper", and which largely stems from the framework originally established by William Labov. Labov himself sometimes referred to this type of linguistics as "secular linguistics", and had resisted the term "sociolinguistics" as he believed there could be no "successful linguistic theory or practice which is not social" (Labov 1972a: xiii). In fact, Chambers and Trudgill suggested in 1980 that "sociolinguistics" is "perhaps too general to be meaningful" and proposed some alternatives, but to no avail (1980: 205). According to Trudgill, the best concise description of this type of linguistics is "the study of linguistic variation and change" (2000: 22), and as Foulkes and Docherty point out, the term that is virtually synonymous with variationist (or quantitative) sociolinguistics is urban dialectology (1999: 2, 4). One may find recent representative work in this field in, amongst others, the Language Variation and Change journal as well as the proceedings of the NWAV conference (New Ways of Analyzing Variation, held annually).

Let us now take a look at what sociolinguistics has usually meant in Serbia, when Labovian, variationist sociolinguistics was first mentioned there, when urban dialectology started being written about, and how dialectology has traditionally been done in Serbia and why. 
Andrej Bjelaković: Whither Variationist Sociolinguistics in Serbia?

\section{The usual meaning of sociolinguistics in Serbia}

There are two works that could be said to provide a paradigmatic insight into what linguists in Serbia, and before that in Yugoslavia, usually meant by sociolinguistics (or rather sociolingvistika).

The first work is Selektivna sociolingvistička bibliografija SFRJ/SRJSCG/Srbija 1967-2014 [Selective Sociolinguistic Bibliography SFRJ/SRJSCG/Serbia 1967-2014] (Bugarski 2015). This bibliography comprises 1428 entries by 580 authors. Looking at the titles, it soon becomes apparent that what preoccupied Yugoslav linguists were primarily sociolinguistic issues, such as bilingualism/multilingualism (mostly at the societal level), language contact, language standardization, language policy and planning, the relationship between language and nation, etc. (this is confirmed by Radovanović and Major 2001). At the forefront was the relationship between Serbo-Croat and other languages spoken in Yugoslavia, as well as the relationship between the so-called "western" and "eastern" varieties of Standard Serbo-Croat. The second work is Sociolingvistika [Sociolinguistics], a textbook by M. Radovanović, originally published in 1979, with the second edition published in 1986 (Radovanović 2003 is a reprint of the second edition). We should note that this is the only textbook/ monograph in Serbian bearing such a title, and there are no works titled e.g. Uvod u sociolingvistiku [Introduction to Sociolinguistics], Sociolingvistički priručnik [A Handbook of Sociolinguistics] or the like. Running at around 280 pages, Radovanović's Sociolingvistika mentions Labov (his seminal 1966 study of NYC speech) only once (2003: 242), while there is no mention of Weinreich, Labov and Herzog (1968), the importance of which as one of the founding texts of variationist sociolinguistics we will note below (Weinreich is only mentioned in the context of his 1953 Languages in Contact). Radovanović, however, rightly points out the importance of certain works by Martinet and Meillet as the forerunners of contemporary sociolinguistics (Radovanović 2003: 230). In other words, the general impression one gets from Bugarski's Bibliografija regarding the type of sociolinguistics typically practised in Yugoslavia is confirmed here. We can see, in other words, that even when Yugoslav linguists did engage in sociolinguistics it was mostly macrosociolinguistics and qualitative sociolinguistics. Quantitative, empirical studies were almost completely absent. 
Now, variationist sociolinguistics, which usually but not always comes in the guise of urban dialectology, can be said to be different from traditional dialectology in two separate ways: in terms of its usual object of study (typically urban vs. rural speech), and, more importantly, in terms of the methodology and theory behind it (more on this below). It is certainly possible to use the methodology of traditional dialectology to study urban speech, just as it is possible to use variationist methodology to study rural communities.

So now we shall first see when the news of this new way of studying language reached Yugoslav shores, so to speak, and then we will look at when certain linguists began calling for urban studies.

\section{The introduction of variationist sociolinguistics in Yugoslavia}

In 1974 Bugarski edited the thematic issue of the journal Kultura (no. 25), containing translations of various sociolinguistic papers, one of which was Labov's "The Study of Language in Its Social Context" (later to become the eighth chapter in Labov 1972a). This was the first time Yugoslav readers had been introduced to concepts such as the Saussurean paradox, indicators, markers, and stereotypes (translated by Bugarski as "pokazatelji", "označivači" and "stereotipi"), as well as the outline of Labov's pioneering 1963 study of Martha's Vineyard.

About a decade later, Bugarski published Jezik u društvu [Language in Society] (Bugarski 1986; the second edition came out in 1996, and was reprinted in 2004), an important work when it comes to popularizing sociolinguistics in the broader sense in Yugoslavia. In addition to mentioning Labov several times (1986: 54-56, 111, 134, 136, 179, 182, 256, 276, 278 279), Bugarski also talks about research by Howard Giles and the matched guise technique, as well as the concept of covert prestige (1986: 146, 141142). Nevertheless, this book, on the whole, devotes comparatively little attention to empirical, quantitative sociolinguistic studies.

\section{Calls for studies of urban speech}

According to Jutronić-Tihomirović (1983) and Bugarski (2009: 14), the very first call to study urban speech in Yugoslavia came from Bugarski in 
1965, in the article "Grad i jezik" [The City and Language] in the journal Izraz (later published in Lingvistika o čoveku (Bugarski 1975 (1st ed.), 1983 (2nd ed.), 1996 (3rd ed.)). Talking about Yugoslav cities, Bugarski writes: "At present, however, we don't know much, and what we do know is neither organised nor documented, but rather intuitive and based on desultory personal observations" (1983: 219), and adds: ${ }^{2}$

Not wanting to focus on the relatively distant future, we would note that we are in need, in desperate need even, of analyses of the present situation. And we do not have such analyses. We simply do not know how we speak in cities today. We have had expertly conducted studies of certain provincial dialects, even of those in remote villages, but the only way to inform ourselves about the way people speak in Belgrade or Sarajevo is through diligently listening and recording what we hear. ${ }^{3}$ (Bugarski 1983: 220-221)

Also in 1965 Milka Ivić published "Jezička individualnost grada" [The Linguistic Individuality of the City] in the same journal (the article later reappeared in O Vukovom i vukovskom jeziku (1st ed. 1990, 2nd ed. 1997):

We are not familiar enough with the extent of nonconformity to the prosodic norm, first of all because, preoccupied with the mission of maintaining the "decasyllabic language", our grammarians were losing their grip on some of the things happening in the linguistic reality of our time. But, regardless of the grammarians and their persistence, events are regularly developing in the direction the general linguistic theory predicts: real command over the linguistic mainstream is being inexorably taken over by the primary disseminators of culture - the cities. [...] In our country, however, it is not clear enough even to all the linguistic experts (then how could it be clear to the wider audience?) that

1 All translations are by A.B. but the originals will also be provided.

2 "Zasad, međutim, ne znamo mnogo, i ne znamo organizovano i dokumentovano, već mahom intuitivno i na osnovu nepovezanih ličnih zapažanja."

3 "[N]e želeći, dakle, da okrećemo pogled relativno daljoj budućnosti, napomenuli bismo samo da su nam potrebne, čak preko potrebne, analize današnje situacije. A mi tih analiza nemamo. Mi jednostavno ne znamo kako danas govorimo u gradovima. Kod nas postoje znalački rađene studije o pojedinim pokrajinskim govorima, pa i o govorima zabačenih sela, ali o tome kako se govori u Beogradu ili Sarajevu možemo se obavestiti uglavnom samo upornim slušanjem i beleženjem onoga što čujemo." 
urban speech should be taken very seriously into consideration as the one crucial phenomenon on which the linguistic future of our culture is based. ${ }^{4}$ (M. Ivić 1997: 165-166)

At the beginning of the following decade, in 1971, outlining the main issues Yugoslav dialectologists would need to deal with, Pavle Ivić writes:

The study of the social stratification of urban speech has become the central topic among dialectologists in the United States in recent years[.] A completely new methodology of such studies has also been developed, using sociological procedures. The achieved scientific results are tremendous. There has been no such research in our region to this day - this is partly because the social differentiation of language has much shallower roots than the geographical one, and is also somewhat due to our dialectologists, even if they are familiar with recent American achievements, never having tried to apply them to the speech in our cities, where there are, after all, problems worthy of attention. These accents, as we all know, are amalgams, just like the population of our cities in which the number of newcomers often exceeds the number of those born in the city. But how does this blend crystallize itself, which linguistic characteristics in it make ground, which of them become general, and which disappear? To what extent does the standard variety win out, and to what extent are features foreign to it adopted in the process of dialect levelling? Are there more noticeable differences in these processes between social classes which, in the end, are not foreign even to us? How quickly are those citizens who came to a city as adults included in its linguistic makeup? What happens to their children, do they retain any trace of their parents' origin, or are they assimilated completely? Answers to such questions

4 "Domašaj [...] nesaobraznosti s prozodijskom normom nije nam dovoljno poznat, $u$ prvom redu zbog toga što su naši gramatičari, obuzeti misijom održavanja 'deseteračkog jezika', gubili kontrolu nad po nečem što se dešava u jezičkoj stvarnosti naših dana. No bez obzira na gramatičare i njihove upornosti, redovno se događaji razvijaju u pravcu na koji ukazuje opštelingvistička teorija: stvarnu komandu nad glavnim tokovima jezika neumitno uzimaju osnovni rasadnici kulture - veliki gradovi. [...] Kod nas, međutim, još nije ni svim jezičkim stručnjacima dovoljno jasno (a kako tek onda može biti jasno široj publici?) da treba zaista sasvim ozbiljno uzeti u razmatranje jezik grada kao onaj bitni fenomen na kojim izrasta jezička sutrašnjica naše kulture." 
Andrej Bjelaković: Whither Variationist Sociolinguistics in Serbia?

are awaiting our dialectologists in the future. ${ }^{5}$ (P. Ivić 2001: 105106)

In 1978 the American linguist Thomas Magner writes:

This focus on the village dialect was certainly relevant up until World War II. However, despite population changes which now favor the city, Yugoslav dialectologists have maintained Vuk's village orientation and largely ignore the speech of city-dwellers. Ironically, the typical Yugoslav dialectologist today is quite likely to have been born in a city but still feels drawn to the rural dialects. (Magner 1978: 465)

At several points in the 1970s, Dušan Jović also points to the need to study urban speech (Jović 1975, Jović 1976a, Jović 1976b, Jović 1978, and Jović 1979):

While dialect systems are most often described with the intention of determining processes and states of historical development, the speech in urban environments usually remains beyond the planned systematic scientific research. [...] The many changes in the stratification of the population, in the material and intellectual domain, lead to very complex hybridization. Features

5 "U Americi je poslednjih godina proučavanje socijalne stratifikacije gradskih govora postalo centralna tema dijalektologa[.] Razrađena je i sasvim nova metodologija ovakvih istraživanja, uz primenu prosedea sociologije. Postignuti naučni rezultati su veoma krupni. Kod nas ovakvih isproučavanja do danas nema - donekle zato što socijalna diferencijacija u jeziku ima kudikamo pliće korene i kraći domašaj od teritorijalne, a pomalo i zato što naši dijalektolozi, ukoliko su i upoznati s najnovijim američkim ostvarenjima, dosad nisu pokušali da ih primene na govore naših gradova, gde ipak ima problema dostojnih pažnje. Ti su govori, to svi znamo, prepuni mešavine, kao što je izmešano i stanovništvo naših gradova gde došljaci najčešće brojno pretežu nad onima koji su rođeni u samom gradu. Ali kako se ta mešavina kristališe, koje jezičke crte u njoj osvajaju teren, koje se uopštavaju, a koje opet nestaju? U kojoj meri pobeđuje književni jezik, a u kojoj se prilikom dijalekatske nivelacije usvajaju i neke pojave koje su mu tuđe? Ima li osetnijih razlika u ovim među društvenim slojevima koji, na kraju krajeva, nisu tuđi ni našoj stvarnosti? Kojom se brzinom uključuju u jezičku sliku nekog grada građani koji su u njega došli kao odrasli ljudi? Šta biva s ljihovom decom, čuvaju li oni još poneki trag porekla svojih roditelja, ili su asimilirana bez ostatka? Odgovori na ovakva pitanja očekuju naše dijalektologe u budućnosti." 
which determine the future physiognomy of the language are being born. ${ }^{6}$ (Jović 1975: 35)

The most important phenomenon of our era must be the fact that, depending on the speed of urbanisation, the centre of linguistic changes is moving into urban communities. It can almost certainly be said that it is there that linguistic processes which determine the future of a language are starting. And it is paradoxical that in many countries it is exactly the speech of those environments that is relatively little researched.7 (Jović 1976a: 734)

Our dialectology doesn't have enough insight into what kinds of linguistic processes exist in dialects. Apart from certain rare exceptions, dialectological work strives to reconstruct an earlier state. As a rule, the real synchronic dialect situation is missing. ${ }^{8}$ (Jović 1978: 497)

Our contemporary dialectology usually does not provide an adequate picture of the state of the language. In dialectological research, the fact that the speech of middle and younger generations is to a greater or lesser extent different than the speech of older generations is rarely taken into account. Obviously, the problem lies in the approach to the given questions, and of course in the aims of the research. Researchers are striving to describe all that has existed in dialects since ancient times, in order to thus preserve it. Sociolinguistic research remains a task for better and more favourable circumstances. ${ }^{9}$ (Jović 1983: 40)

6 "Dok se dijalekatski sistemi opisuju najčešće s ciljem da se utvrde istorijski razvojni procesi i stanja, dotle jezik urbanih sredina ostaje uglavnom izvan planskog i sistematskog naučnog izučavanja. [...] Silne promene u stratifikaciji stanovništva, u materijalnom i intelektualnom domenu dovode do veoma složenih ukrštanja. U jeziku se rađaju fenomeni koji određuju njegovu fizionomiju i u budućnosti."

7 "Najbitniji fenomen naše epohe sigurno je to što se u zavisnosti od tempa urbanizacije težište jezičkih promena pomera u urbane zajednice. Gotovo se bez rezerve može reći: u njima se stvaraju jezički procesi koji određuju budućnost jezika. I paradoksalno je što se u mnogim zemljama upravo jezik tih sredina srazmerno malo izučava."

8 "Naša dijalektologija nema dovoljno uvida u to kakvi sve jezički procesi u dijalektima postoje. Sem retkih izuzetaka dijalektološki radovi nastoje rekonstruisati neko starije stanje. Po pravilu, izostaje stvarna sinhrona dijalekatska situacija."

9 "Naša savremena dijalekotlogija uglavnom ne daje pravu sliku stanja jezika. Retko se u dijalektološim istraživanjima uzima u obzir činjenica da se jezik srednjih i mlađih 
At the same 1983 conference, P. Ivić again points out:

In our field, sociolinguistics has often been on the agenda lately. Plenty of accurate things have been said, but we mostly stopped at competently reporting the scientific results from the rest of the world, or contemplating our situation, in general, most often adequately, but by guessing, impressionistically, without any empirical results. It would be good if that first phase of approaching the problem were followed by the phase of concrete studies. ${ }^{10}$ (P. Ivić 1983: 204)

Also in 1983 Dunja Jutronić-Tihomirović joins the calls:

The ways of evolution, or change, of the dialectal and of the standard in the urban environment are still waiting to be described. This hybridization is noticeable in the speech of the middle and young generations with clear changes in the dialect, so it can rightly be said that our dialectology does not provide us with the true state of things in the dialects. [....] Other researchers have agreed that important linguistic processes which impact contemporary language development do not take place in rural areas anymore, but in our cities. ${ }^{11}$ (Jutronić-Tihomirović 1983: 201)

In the early 1990s, P. Ivić repeats that "a great future" lies in store for sociolinguistic research and, commenting on the thesis by the French linguist Paul-Louis Thomas, adds that "what Thomas did in Niš should be done in all cities" (Ivić 1994: 70) (see below for more on this work by Thomas).

generacija više ili manje razlikuje od jezika starijih. Očigledno je problem u pristupu datim pitanjima, i naravno ciljevima istraživanja. Nastoji se opisati sve što u dijalektima od starine postoji da bi se tako zapisano sačuvalo. Sociolingvistička istraživanja ostaju kao zadatak za neku bolju i povoljniju priliku."

10 "Kod nas je u poslednje vreme sociolingvistika često na dnevnom redu. Rečeno je mnogo tačnih stvari, ali se uglavnom ostajalo na kompetentnom prenošenju rezultata svetske nauke, ili se razmišljalo o našim prilikama načelno, uopšteno, najčešće opravdano, ali napamet, impresionistički, bez empirijskih rezultata. Dobro bi bilo kad bi iza te prve faze prilaženja problematici sad odmah sledila faza konkretnih proučavanja."

11 "Kako se razvija, tj. mijenja dijalekatsko a kako standardno na urbanom prostoru još čeka da bude opisano. Ovo ukrštanje uočljivo je u govoru srednje i mlađe generacije s jasnim promjenama u dijalektu tako da se s pravom može reći da naša dijalektologija ne daje pravu sliku jezičnog stanja u dijalektima.[...] Sudionici su bili saglasni da se važni jezični procesi koji utječu na današnji razvoj jezika ne odigravaju više u seoskoj sredini već u našim velikim gradovima." 
We will finish this overview by citing Rajić, writing at the turn of the century, many decades after the first calls:

Our dialectology is timeless, because there are no longitudinal studies (studies of changes in dialects). There are also no significant studies of urban speech. For example, a quarter of Serbia's population lives in Belgrade and we can ask with justification if it is more important, both from the viewpoint of the history of language and of dialectology to research the speech in Belgrade or the speech of a demographically insignificant village in Šmadija. ${ }^{12}$ (Rajić 2000: 117)

So it seems that at least some linguists were aware that "[n]o serious perspective on dialectology can grant urban research and variation theory less than a central role" (Chambers and Trudgill 1998: 188). However, all of these calls, until very recently, fell on deaf ears. ${ }^{13}$

\section{On the main differences between traditional dialectology and contemporary dialectology}

Dialectology as a separate field, at least in Europe, is usually tied to the work of Georg Wenker in Germany and Jules Gilliéron in France from the last quarter of the 19th century. ${ }^{14}$ The pioneering efforts of Milan Rešetar and Aleksandar Belić in what today would be called the BCS-speaking area (Bosnian-Croatian-Serbian) followed shortly thereafter. The primary motivation of these early dialectologists was closely related to the history of language. Namely, studying the speech of small, rural, isolated communities

12 "Dijalektologija nam je vanvremenska, jer nema longitudinalnih istraživanja (istraživanja promena u dijalektima). Nema ni značajnijih istraživanja gradskih govora. Na primer, Beograd ima četvrtinu stanovništva Srbije i opravdano je postaviti pitanje da li je važnije i sa tačke gledišta istorije jezika i sa tačke gledišta dijalektologije istraživati govor Beograda ili govor nekog demografski beznačajnog sela u Šumadiji."

13 We will note here that even in recent dialectological handbooks and surveys published in Serbia, there is typically no mention whatsoever of urban dialectology (e.g. Simić 1995, Bogdanović and Marković 2000, Remetić and Dragičević 2001, Marković 2007, Remetić 2016).

14 For more on the beginnings of continental and British dialectology, see respectively Malkiel (1984: 37-40) and Malkiel (1984: 43-45), and also Chambers and Trudgill (1998: 13-20). 
was a window to the past, and the features in informants' speech were living fossils, remnants of days gone by. This synchronic research, simply put, provided insight into the diachrony of the language (Stoddart et al. 1999: 82, Chambers and Trudgill 1998: 30). In accordance with that, Remetić, writing about the beginnings of Južnoslovenski filolog says that contributions to the journal were, from the start, "[in] accordance with the principles of the dialectological school of Belić (and P. Ivić) by which two national linguistic disciplines, complementary to each other - history of language and dialectology - create a natural unity" ${ }^{15}$ (Remetić 2013: 13-14).

Regarding informant selection, P. Ivić, describing Belić's work, says he would choose older farmers, noting "and those, as a rule, serve as informants when we study the linguistic features of dialects"16 (P. Ivić 1999: 413-414). Similarly, describing his own methodology at the very end of the 20th century Bukumirić writes: "In the choice of informants, we started from familiar criteria. It was desirable that they be illiterate older women, born and married in the same village, who hadn't spent much time away, where they could have been exposed to the influence of a different dialect" ${ }^{17}$ (Bukumirić 2003: 48).

To sum up, traditional dialectology is characterized by studying rural speech and focusing on the oldest generation of usually non-educated speakers. Once the "ideal" informants are located, their speech is usually portrayed as homogeneous and described qualitatively - the features are merely listed, and variation is suppressed and omitted from the description, thereby eliminating the need for the quantitative component (features are portrayed as either present or absent, so there is no need to introduce frequency).

So then, what are the most important methodological and theoretical differences between traditional dialectology and variationist sociolinguistics (regardless of whether one employs the latter to study urban or rural speech communities)? The key variationist axiom is that "a language system that

15 “[u] skladu sa načelima belićevske (i ivićevske) dijalektološke škole, po kojoj dve nacionalne, međusobno komplementarne, jezičke discipline - istorija jezika i dijalektologija - čine prirodnu celinu."

16 "a to su, po pravilu, informatori o jezičkim osobinama dijalekata"

17 "[U] izboru informatora polazilo se od poznatih kriterijuma. Bilo je poželjno da to budu nepismene žene $u$ odmaklim godinama, rođene $i$ udate $u$ istom selu koje nisu duže vreme boravile na strani da bi mogle biti izložene uticaju drugog govora." 
did not display variability would not only be imaginary but dysfunctional, since structured variability is the essential property of language that fulfils important social functions and permits orderly linguistic change" (Milroy and Gordon 2003: 4). Thus, instead of shoving linguistic variation under the proverbial carpet, sociolinguists embrace it:

$[\mathrm{T}]$ he variable elements $[. .$.$] have traditionally been relegated to$ a kind of linguistic scrap heap, under the name of "free variants," "social variants," "expressive variants," and similar terms.

In the approach we shall now follow, no such liberties with the data will be permitted. Whenever we hear an inconsistency in someone's speech, we must ask: Is this variation consistent? Is it part of a larger pattern? This attitude is grounded in the conviction that language is no less determinate than other forms of social behavior. The amount of randomness in this system is relatively small: behavior that seems at first to be "free" or "random" is discovered on closer examination to be determined by factors accessible to the linguist. (Labov 2006: 31-32)

Now, these linguistic variables (the presence or absence or the relative frequency of variants in an individual's speech) will correlate with factors such as age, sex/gender, class, ethnicity, religion, membership in certain social networks and communities of practice (Wolfram 2006: 336), and crucially, the style of speaking, because, lest we forget, there are no singlestyle speakers (Labov 1972a: 208). Of course, linguistic variables also correlate with purely linguistic factors such as:

$[\mathrm{P}]$ honetic environment (e.g., preceding and following segments, stress patterns), hierarchical status (e.g., syllable position), and grammatical status (e.g., type of morpheme)[.] There also may be other factors, such as the lexical condition that high frequency words favor a variable process over low-frequency words[.] For morphological and syntactic variables, lexical category (e.g., noun vs. verb), phrasal composition (e.g., NP vs. VP, heavy vs. light phrases), co-occurrence relations (e.g., concord, phrasal complements), embedding (matrix vs. embedded clause), and adjacency conditions (proximate vs. distal) may be relevant factors affecting the relative usage of fluctuating variants. (Wolfram 2006: 335) 
This synchronic variation is often a reflection of diachronic change (Bailey 2013: 85), as all linguistic change involves variability, but not all instances of variability involve change (Weinreich et al. 1968: 188). Variationist sociolinguistics has thus helped solve some of the most important puzzles of historical linguistics regarding language change (see Weinreich et al. 1968: 187-188, and Labov's three-volume magnum opus Principles of Linguistic Change, Labov 1994, 2001, and 2010). As Wolfram and Schilling point out:

A traditional dialectologist, frozen in the time frame of half a century ago, would hardly recognize what constitutes dialect study today. The underlying motivations for studying dialects in the present day may be well established in the historical record, but the field has undergone some profound changes in its foci and methods. (2015: 24)

\section{Some possible reasons for the current state of affairs}

Now we shall turn to some possible reasons why variationist sociolinguistics and urban dialectology have been absent to such a degree first in Yugoslavia and then in Serbia.

The first reason, which we may call ideological, refers to the concern about the "impurity" of urban dialects and generally about the speech of anyone who is not a non-mobile older rural speaker. As Milroy and Gordon put it:

One of the most pervasive assumptions underlying the traditional dialectological method is that a particular form of a dialect - usually represented by the speech of a conservative, socially marginal speaker - is in some sense the "genuine" or "pure" form. The main difference between early and more recent (variationist) urban studies is that by employing the concept of the linguistic variable the latter examine alternative linguistic forms, seeing this alternation as a significant property of language rather than admitting the concept of the "pure" or "genuine" dialect. This difference in the conception of what constitutes a dialect has important implications for subject selection procedures. (Milroy and Gordon 2003: 16) 
A paradigmatic example of this attitude we find in Ćupić (1983):

Regardless of all of this, we are certain we will not be wrong to conclude that only rural environments are areas that can have compact dialects, or microdialects, while the same cannot be said of cities [...] Still, it is only in rural environments that we can come across pure vernacular unspoiled by urbanisation. ${ }^{18}$ (Ćupić 1983: 56)

Cities are places where people from the most remote and dialectically very diverse regions meet, therefore there is not a single city left whose dialect compactness has not been broken into pieces. [...] So, today they are ruled by a dialect mixture; their speech is an amalgam of different dialects and literary language. [...] The old citizens cannot provide compactness of any sort; amalgamations are multilateral, or better yet - versatile. [...] Given that our cities develop under such conditions, is it possible to develop a thesis about speech in those cities? Definitely not, or at least not until cities are finally formed and their physical spread has stopped and, along with that, until citizens have spent multiple decades in such conditions. Only then could it impact the 'levelling' of speech characteristics. ${ }^{19}$ (Ćupić 1983: 59-60)

To which P. Ivić replied:

The challenges a researcher of urban speech faces have been justifiably stressed here, with urban speech being ungraspable because of its deep stratification, and this in two dimensions, the social dialectal one, which comes about in the clash between

18 "No, bez obzira na sve to, sigurni smo da nećemo pogriješiti ako konstatujemo da su samo seoske sredine područja koja mogu imati kompaktne govore, ili mikrodijalekte, dok se za gradove to ne može reći [...] Pa ipak, isključivo u seoskim sredinama možemo nailaziti na čiste narodne govore, nenatrunjene urbanizacijom."

19 "Gradovi su stjecište stanovnika najudaljenijih i dijalekatski vrlo različitih teritorija, tako da nije ostao skoro ni jedan čija dijalekatska kompaktnost nije razbijena u paramparčad. [...] Tako da u njima danas vlada govorni amalgam, njihov govor je smješa različitih dijalekata i književnog jezika. [...] Staro stanovništvo ne može da obezbijedi kompaktnost nikakve vrste, miješanja su višestrana, bolje reći - svestrana. [...] Ako je riječ o takvim uslovima razvoja naših gradova, da li je moguće razvijati tezu o govorima tih gradova? Svakako - ne, ili ne makar sve do onda dok se konačno ne oforme gradovi i ne zaustavi njihovo fizičko širenje $i$, uz to, ne prođe više decenija života stanovništva u takvim uslovima. Tek bi to moglo da utiče na „nivelaciju“ govornih osobina.” 
native and immigrant speech, and in the mixing of the various accents of the immigrants themselves. However, I would like to point out that there does exist a subvariety that can be considered the most typical for the given city. That is the speech of the youth born in the city, which is (provided that all are equally educated) fairly unique, no matter where their parents came from. That is what 'grows from the ground', or better yet 'from the asphalt', and is strengthened and evened out when the children or the youth talk among themselves. At the same time, this is also the kind of speech the future belongs to. ${ }^{20}$ (P. Ivić 1983: 205)

Škiljan on the other hand correctly pointed out:

But in order to actually achieve [the development of our sociolinguistics], one deep-rooted belief must be overcome: namely, under the influence of tradition, but also for different ideological and petty political reasons which would deserve a separate analysis, in the minds of those who deal with language in any way (but also in the minds of 'ordinary' speakers) a horizontal diversity still often prevails over the vertical. ${ }^{21}$ (Škiljan 1980: 959)

Related to this is the tacit presence of the "pastoral tradition", the ideological stance that relates the countryside with purity and authenticity (Petrović 2003, Petrović 2009: 20). As Bugarski states "in a typically romantic view, idealised and even mythologized, the village is seen as the

20 "Ovde su s pravom isticane teškoće s kojima se sukobljava proučavalac gradskog govora, neuhvatljivog zbog svoje duboke raslojenosti, i to u dve dimenzije, socijalnoj dijalekatskoj, onoj koja nastaje u sudaru između zatečenog i došljačkih govora, i u ukrštanju raznorodnih govora samih doseljenika. Ipak, skrenuo bih pažnju na to da postoji govorni sloj koji se može smatrati najtipičnijim za dati grad. To je govor omladine rođene u gradu, koji je (pod uslovom jednake školovanosti) prilično jedinstven, bez obzira na to odakle potiču roditelji. To je ono što ,izrasta iz tla“, tačnije „iz asfalta“, i što se učvršćuje i ujednačuje u dodirima među decom, odnosno omladinom. To je ujedno i govor kojem pripada budućnost."

${ }_{21}$ "No da bi se [razvitak naše sociolingvistike] uistinu ostvario, treba prevladati jedno duboko ukorijenjeno uvjerenje: naime, pod utjecajem tradicije, ali isto tako i iz različitih ideoloških i politikantskih razloga koji bi zasluživali zasebnu analizu, u svijesti onih koji se bilo na koji način bave jezikom (pa i u svijesti „običnih“ govornika) nerijetko horizontalna raznolikost i dalje znatno preteže nad vertikalnom.” 
sources of pure, genuine and unspoiled speech"22 (2009: 16). Or as Gal summed up Williams: "[a] rhetorical convention which continually looks back, often nostalgically and for moral guidance, to a lost, but supposedly more pristine, rural, homogeneous, and authentic past" (Gal 1996: 587, Williams 1973). ${ }^{23}$

Related to this is also the view that if an idiom (dialect, language, etc.) is not "pure" and "authentic" it is not, in a sense, real; it does not exist as a separate entity. ${ }^{24}$ Finally, there is the underlying assumption that time starts passing only after a dialect has been encountered for the first time, i.e. that at the moment of its first being described it is "crystalized" and "pure", while all subsequent innovations are in fact corruptions:

Gal (1989: 315-316) notes that "announcing the extinction of cultures, languages and dialects at the moment they are first described by outsiders has been a rhetorical construct central to Western ethnography"; the same constructs are met in the writings of ethnographers and dialectologists in the Balkans, where any kind of language change is seen as a positive sign of extinction and corruption of a genuine language form. (Petrović 2003)

There is a kind of folk-myth deeply embedded among linguists that before they themselves arrived on the scene there existed a homogenous, single-style group who really "spoke the language." Each investigator feels that his own community has been corrupted from this normal model in some way - by contact with other languages, by the effects of education and pressure of the standard language, or by taboos and the admixture of specialized jargons. (Labov 1972a: 203)

22 "u jednom tipično romantičarskom viđenju, idealizovanom i čak mitologizovanom, selo je sagledano kao izvorište čistog, nepatvorenog i neiskvarenog jezika"

23 According to Petrović (2009: 21) the characterization of certain varieties as "corrupt" begins in Serbia with Vuk Karadžić, who was famously disparaging of the Serbian spoken in Vojvodina.

24 As Friedman puts it: "contact = impure = bad = illegitimate", adding "if a language is portrayed as not having a distinct lexicon owing to being hopelessly mixed as the result of prolonged contact and subordination, then it can be treated as not being a 'real' language and thus unworthy as the characteristic of a nation, which in turn has no right to territory or a state" (1997: 7). 
One of the things this leads to is the false dichotomy between two supposedly monolithic entities: the "književni jezik" as described in the normative works, and the "pure", "authentic" dialect. ${ }^{25}$

An example of this confused view is found in Tomic (2012a). The author describes the speech of Vranje children, aged six, and observes how they tend to use more non-standard features talking to one another than when addressing the teacher or when they pretend to be adults while roleplaying. This leads her to conclude that the children use "two linguistic systems depending on the situation" (Tomić 2012a: 253), whereby the aim of her research and many other similar studies is to determine "to what extent standard speech disturbs the dialect system". ${ }^{26}$ In other words, she envisions two separate systems, the "true" prizrensko-timočki dialect as first described by Belić more than a century ago, and the standard language. Of course, there are no two systems; there is only one system which is, as all language systems are, heterogeneous, displaying structured variability. The children were merely exhibiting normal stylistic variability according to the situation.

As we have seen, Serbian linguists have considered the language of cities and towns to be a kind of patchwork of features present in either rural dialects or the standard variety, thereby ascribing the creative power to the "authentic" language of rural communities and the autochthonous linguistic development therein. However, sociolinguistics has shown that it is precisely the cities, and the type of social contact and social structure typical for urban communities, that encourage linguistic innovation (Milroy and Milroy 1985, Milroy 1992: 175-200), meaning that it is precisely there that we may expect completely new forms to arise.

Since all varieties of all languages are changing all the time (Milroy 1992: 1-4, Aitchison 2001), then the variety spoken in each community, urban or rural, is undergoing linguistic change with every passing moment, and has been doing so since time immemorial (cf. the uniformitarian principle, Labov 1972b: 101, Labov 1972a: 275, Lass 1997: 28). This

${ }^{25}$ Cf. Milroy et al. (1994: 1-2): "for both methodological and analytic reasons, the simplistic opposition between standard and non-standard should be superseded by an approach that recognises gradations in terms of local and non-local, with the standard (in so far as it can be defined as a variety) being perhaps the ultimate in a non-localised variety of language".

26 „dva jezička sistema u zavisnosti od situacije“; „u kojoj meri standardni jezik narušava dijalekatski sistem“ 
means that every single community, no matter how small or isolated, at every point in its history, has displayed linguistic variation. The first traditional dialectologist to notice and fully address this is said to be Louis Gauchat, while studying the language of the small Alpine village of Charmey (Gauchat 1905 [2008], Bugarski 1986: 243, Chambers 2008, Chambers and Schilling 2013: 3-4). The Neogrammarians of Gauchat's time wrote this off as "dialect mixture", being theoretically ill-equipped to deal with the implications of his description, but as Labov points out:

[W]e find that most investigators describe their own community as exceptional, rife with dialect mixture and chaotic variation as compared to the homogeneous nature of traditional speech communities. But such homogeneous communities are also myths. As Gauchat showed (1905), even the most remote Swiss village shows systematic variation across sex and age group (Labov 1972b: 109).

What we need to do, then, is to "dissolve the assumed association between structure and homogeneity" (Labov 1972a: 204). Once these theoretical and ideological hurdles are overcome, a new world of data regarding changes already finished and those currently under way would become available:

But if new data has to be introduced, we usually find that it has been barred for ideological reasons, or not even been recognized as data at all, and the new methodology must do more than develop techniques. It must demolish the beliefs and assumptions which ruled its data out of the picture. Since many of these beliefs are held as a matter of deep personal conviction, and spring from the well-established habits of a lifetime, this kind of criticism is seldom accomplished without hard feelings and polemics, until the old guard gradually dissolves into academic security and scientific limbo. (Labov 1972b: 99)

The other major reason for the described state of affairs that suggests itself is the fact that, on the one hand, Yugoslav linguists seem to have been mostly ignorant both of the sociolinguistic theory and of the finer points of methodology that follows variationist research, while, on the other hand, those few who were aware of it never employed it. This has been pointed out by Jutronić-Tihomirović: 
There is an additional reason why dialectological studies have not progressed: The Slavists who do most of the dialectological work are not very well acquainted with the most recent advances in Anglo-American (socio) linguistics. On the other hand, general linguists, most of whom are Anglicists, do not feel they should intrude on the territory of the Slavists. (Jutronić-Tihomirović 1989: 147)

Two factors, we would say, conspired here: the tribalism and isolationism in the Yugoslav scientific community when it comes to linguistics, i.e. the division into groups based primarily on university department (one was primarily a "Serbo-Croatist" or a "Romanist" or an "Anglicist", instead of a syntactician, a phonetician, etc.); and the unwillingness of a part of the said community to keep abreast of the new developments in linguistics as such (partly, perhaps, because these developments were coming from the English-speaking part of the world).

In other words, linguists who used to do thorough field work and research tended to be ignorant of post-1960s theory and methodology, and those who were not ignorant of these advances seemed, for various reasons, to lack the impetus to go out and conduct proper empirical investigation.

\section{What little has been done}

Even though thus far we have talked about Yugoslav linguists, primarily because the original conditions that led to a lack of variationist studies were more or less the same throughout Yugoslavia, we shall now focus only on Serbia ${ }^{27}$, and try to determine to what extent urban speech has been studied and to what extent researchers have moved away from the methodology of traditional dialectology. Most of the works listed below were cited in Bošnjaković (2009a), Marković (2012), Marinković and Marinković (2012), Vasić et al. (2007) and Vučković (2009).

First of all, we will put aside the works that deal with regional vocabulary in towns, i.e. dialect lexicography. Furthermore, we will not concentrate on the works that deal with language in the media, even though these often effectively talk about the features of more formal, careful styles

27 Though we feel we would be remiss not to at least mention in passing Dunja Jutronić's monograph about the speech of the Croatian city Split (Jutronić 2010). 
of Belgrade and Novi Sad speech, depending on which TV and/or radio stations are under consideration; for a list of these see Bošnjaković (2009a: 66). Finally, before we turn to our main groups of studies, the existence of the Novi Sad speech corpus should be mentioned (see Savić 1999 and references therein.)

The first group of studies we will look at are those that examine the Serbian spoken in towns or cities in Serbia, but which definitely do not use and make no attempt at using variationist methodology.

A subgroup within this group comprises studies which fall within the domain of acoustic phonetics (but not sociophonetics), which nonetheless used informants from urban centres; this means they provide us with at least some data on urban speech in contemporary Serbia. Of these we will mention Sredojević (2017), which used 45 informants, almost all students, from Novi Sad (see also Sredojević 2005a, Sredojević 2009a and Sredojević and Subotić 2011), Sredojević (2015b), which examined a feature in the speech of Southeastern speakers studying in Novi Sad (Sredojević's work focuses on pitch-accents), Marković and Bjelaković (2009a) and (2009b), which looked at vowel length in 10 Novi Sad speakers, Gudurić (2009), which examined /ž/ and /šs/ in 13 Novi Sad speakers, Lončar Raičević (2016a) and the latter portion of (2016b), which used informants from Užice, and Batas (2014), which used 14+24 student informants from a variety of towns, mostly from Western Serbia, Vojvodina and Belgrade.

The next subgroup comprises papers which briefly cite some features that the author has noticed typically while living in the city in question (usually these are impressionistic remarks about some of the speech features of Belgrade or Novi Sad). In other words, there is no mention of the research methodology etc., rather just some off the cuff observations, superficial sketches of the accent/dialect in question. Often the first person credited for describing urban features of a Serbian variety is Miloš Moskovljević, who in a short 1921 paper listed some of the features he had noticed in the speech of Belgrade; Moskovljević (1939/1940) carries on in a similar vein, focusing on phonetics, as do Belić (1929: 1073) and Belić (1939). Miletić (1952: 101-102) also briefly lists some accentual features he had noticed in the speech of Belgraders, as does Vukomanović (1967). Rajić (1980-1981) briefly reports on the general results of the survey he conducted among a few dozen speakers of varying backgrounds regarding attitudes to the standard variety and regional dialects. 
Some impressionistic remarks about the non-standard features of the speech of Belgrade and Novi Sad can also be found in Pešikan (1991: 66), Petrović (1996), Petrović (2001), Vasić et al. (2007), Stijović (2009), Petrović and Gudurić (2010: 369-383 et passim), and Subotić et al. (2012: 102-103).

An interesting, more or less unique, place is occupied by Magner and Matejka's 1971 study. The two American linguists endeavoured to examine the perception of pitch-accents in several Yugoslav towns. They tested 1600 high school students in 20 cities and towns on the ability to perceive the prosodic distinctions of the Vukovian accentual system by playing them a set of sentences containing minimal pairs. (Also see Ivić's critique thereof, 1996: 165-169).

The remainder of this group consists of studies which use the methodology of traditional dialectology but look at urban speech. In other words, a handful of "representative" informants are chosen and their speech - only one style thereof - is described. In addition to this, many of these studies do not provide a detailed description of the urban idiom in question, but only focus on one or a few features, often comparing them to the standard variety and to the traditional dialect of the region (exceptions are Stevanović (1950), Mihajlović (1977), Remetić (1996) and Toma (1998), which are monograph-length descriptions, characteristic of Srpski dijalektološki zbornik). In this group we find the following studies:

Stevanović (1950) provides a description of the speech of Serbs from Đakovica, focusing only on speakers who had been living there before World War I.

Mihajlović (1977) is a study of Leskovac speech based on 18 mostly elderly informants, though not all of them uneducated.

Magner (1984) asked university students from Niš to translate a short text into the variety they would normally speak at home; two of the translations are provided in the paper.

Jerković (1992) gives a sketch of Bečej speech based on 20 elderly informants.

Remetić (1996) provides a description of Prizren speech based on seven elderly informants.

Ćirić (2008) reports on the speech of two elderly informants from Pirot.

Lončar Raičević (2014) looked at the presence of the non-initial short falling accent in the speech of Užice. 
Miloradović (2014) briefly mentions some of the current features of Paraćin speech.

Bošnjaković (2016) provides a description of the speech of a single elderly Belgrader from Dorćol (b. 1916).

The most detailed traditional description of an urban Serbian variety is provided by the French linguist Paul-Louis Thomas (Toma 1998). His monograph description of Niš speech is also based largely on traditional methodology, but Thomas a) compares elderly speakers from Niš and those from surrounding villages; $b$ ) provides a sophisticated phonetic description (he distinguishes 18 vowel qualities: $\mathrm{i}, \mathrm{i}^{\mathrm{e}}, \mathrm{e}^{\mathrm{i}}, \mathrm{e}, \mathrm{e}^{\mathrm{a}}, \mathrm{a}^{\mathrm{e}}, \mathrm{a}, \mathrm{a}^{\mathrm{o}}, \mathrm{o}^{\mathrm{a}}, \mathrm{o}, \mathrm{o}^{\mathrm{u}}, \mathrm{u}^{\mathrm{o}}, \mathrm{u}$, $\left.\mathrm{e}^{\curvearrowright}, \partial, \mathrm{o}^{\curvearrowright}, \partial^{\mathrm{a}}, \mathrm{a}^{\curvearrowright}\right)$, though still avoiding quantitative analysis; and as an aside (1998: 434), there is a sociolinguistically aware comparative account of two female speakers, one of whom was leading an isolated life, while the other had extensive contact with her children and grandchildren.

This leads us to Bošnjaković (2009), Govor Novog Sada [The Speech of Novi Sad]. This collection of papers (the first of two volumes, the second being Vasić and Štrbac 2011), opening with a theoretical chapter by Bugarski, is a landmark in Serbian sociolinguistics. However, while all the papers in the volume obviously deal with urban speech, specifically that of Novi Sad, only a minority use variationist methodology, as we shall now see.

Sredojević (2009a), as mentioned above, belongs to our previously mentioned group of acoustic studies that use informants from urban centres (this paper looks at the short rising accent in the speech of 10 students from Novi Sad), as do Marković and Bjelaković (2009a) and (2009b), which looked at vowel length, both accented and unaccented, in the speech of 10 informants, as well as Gudurić (2009), which examined the production of fricatives $/ \check{\mathrm{z}} /$ and $/ \check{\mathrm{s}} /$.

Bjelaković and Marković (2009) contains an acoustic element related to vowel quality (13 informants), but is otherwise a qualitative/traditional study of the post-accentual length (26 informants).

Dragin (2009) and Sredojević (2009b) both look at the speech of newsreaders on local TV channels, but again neither of them is quantitative.

Stokin (2009) uses two elderly informants and provides a traditional look at their pitch-accent system with regard to different morphological categories.

Ajdžanović and Alanović (2009) look at the accent of adjectives in the speech of students, again, with no quantitative or variationist 
elements (though information on their and their parents' place of birth is provided).

Štrbac (2009), similarly, just cites examples of ikavisms in her informants' speech $(n=15)$, but information regarding their age, education and occupation is provided.

Finally, Bošnjaković and Radovanović (2009) look at the speech of people, mostly refugees, originally from Croatia and Bosnia and Herzegovina who had settled in Novi Sad. They make sure to provide data on the age of speakers, as well as their occupation and regional background, but otherwise their analysis is qualitative/traditional.

This leaves us with the only three contributions in this collection, namely Bošnjaković (2009b), Bošnjaković and Urošević (2009) and Bošnjaković (2009c), which actually use elements of variationist methodology. Bošnjaković (2009b) correlates the age of his 13 informants with the frequency of one variable, while also providing information about their education and occupation, though the difference in the type of tokens across different speakers was potentially problematic, as the author himself points out. Similar holds true for the other two papers.

Due to space constraints we will only briefly turn to the second volume of Govor Novog Sada (Vasić and Štrbac 2011). The crux of this volume is based on an extensive written questionnaire, a lot of which concerned lexis, filled out by 234 informants (a similar but less extensive questionnaire was administered by Bošnjaković (2009d) in a few village and town primary schools in Banat). The informants' age and level of education were provided, and the analysis sections often involved the frequency of each of the offered answers. We would also like to single out Sredojević (2011), an attitudinal study, perhaps the first of its kind in Serbia, which involved playing recordings of Novi Sad speech to a group of informants, a quantitative analysis of whose responses was then provided.

The remaining group comprises studies which make use of the sociolinguistic methodology at least to a degree, if only to acknowledge the differences between speakers of different ages (we will explicitly state if a study provides any quantitative data).

An early example of a researcher who didn't turn a blind eye to variation while using traditional methodology is, according to Bošnjaković (2012), Nevenka Sekulić (1981). We would add to this P. Ivić (1991), written in 1979, in which the author actually provides quantitative data on an unexpected feature he encountered in a Srem village. 
Jović (1979) provides a table showing the main accentual differences between three generations in the Aleksandrovačka Župa region. In Marinković (1994), we find brief general remarks on the main differences between older, middle-aged and younger rural speakers in the Vranje region. We find similarly impressionistic remarks on the internal variation in Vlasotince in Stanković (1997). Bošnjaković (2003) provides a more detailed list of examples regarding the pitch-accent system in the village of Batovac, with some of them divided into groups according to the age group; the same approach was used by Čudomirović (2007) in Batuša. Bošnjaković (2012) examines intraspeaker as well as interspeaker variation regarding pitch-accents in a Banat village, using seven informants of varying ages, referring to the variationist concept of apparent time, and Bošnjaković and Knjižar (2012) examine three variables in Bunjevac speech using six informants - these two studies do use the quantitative approach.

Tomić (2012b) looks at the place of accent in the speech of Vranje preschool children, providing quantitative analysis. Vuletić (2014) conducts a survey (192 informants from Šabac and Sremska Mitrovica) regarding language attitudes (especially with regard to the standard variety and regional varieties) and provides quantitative analysis with regard to informants' location, gender, age, occupation and education. Trajković (2015) devotes most of her thesis to a description of the rural speech of Preševo in a traditional vein; however, the final section (2015: 336-406) uses variationist methodology (taking into account the speakers' age and education, and providing quantitative data as well). Finally, Lončar Raičević (2016b: 34-48) uses quantitative methodology in one of the sections of her thesis to show that a feature is on the decline in rural Zlatibor speech (11 informants are used, born between 1929 and 2004).

\section{Conclusion and future goals}

We have seen that what few studies of urban speech exist in Serbia tended to use the methodology of traditional dialectology; the use of variationist methodology is as yet sporadic and uncertain. We are still some way away from what Labov achieved for New York City in 1966 (Labov 2006). Researchers are often still engaged in "a kind of linguistic archaeology", eschewing more representative populations (Chambers and Trudgill 1998: 30). What Trudgill said of Britain in 1974 is still true of Serbia today: "the 
considerable amount of rural dialectological work that has been carried out in Britain has left the linguist singularly ignorant about the way in which most of the people in Britain speak" (1974: 4). Indeed the same was said by Bugarski in 1965: "we are in need, in desperate need even, of analyses of the present situation. And we do not have such analyses. We simply do not know how we speak in cities today" (Bugarski 1983: 220-221).

This lack of knowledge, the state of being "safely semi-ignorant" ("bezbedna poluobaveštenost", Bugarski 1986: 44), among other things, allows for untenable claims to be made, and shedding light on the contemporary regional varieties of Serbian could have certain implications for the supraregional standard variety. ${ }^{28}$

Also, a thorough analysis would show us which features of traditional dialects have been abandoned in which region, and which features, some of them perhaps new, have attained local prestige and serve the purpose of reaffirming regional identity (cf. Kerswill 2003: 3 and the young English northerners not wanting to sound like old northerners, but also not wanting to sound like southerners).

Seeing how major urban centres influence the geographic areas around them and how linguistic innovations emanate from them (see Kapović 2004 for a look at the situation in Croatia), and seeing how major levelling processes are taking place all over Europe (Kerswill 2013), we can expect to find out that old isoglosses have shifted, and perhaps disappeared, while new isoglosses may have formed (cf. the criteria used by Labov et al. 2006 to draw regional boundaries).

A useful place to begin, for the uninitiated, would be to read key foundational texts and up-to-date handbooks (e.g. Labov 1972, Milroy and Gordon 2003, and Chambers and Schilling 2013). A potential task would be to collect all the extant tapes made in the course of traditional dialectological research in the previous century and reanalyze the material, paying close attention to intraspeaker and interspeaker variation. The ultimate goal, of course, would be to thoroughly describe the speech of all major speech communities, especially the main urban centres, with all of their internal variation, style shifting, and change in progress (Labov 1972b: 108).

28 A study similar to Kristiansen (2001) would be very welcome, as it would determine which varieties are actually prestigious, and considered appropriate in various situations. 


\section{References}

Aitchison, J. (2001). Language Change: Progress or Decay?. $3^{\text {rd }}$ ed. Cambridge: Cambridge University Press.

Ajdžanović, M. and M. Alanović (2009). Prozodijske odlike pridevskih vidskih parova u govoru Novog Sada. In: Bošnjaković, Ž. (ed.) (2009), 235-245.

Batas, A. (2014). Fonetska i akcenatska promenljivost reči u kontinualnom govoru. PhD dissertation. University of Belgrade.

Belić, A. (1929). Štokavski dijalekat. In: Stanoje Stanojević (ed.) Narodna enciklopedija srpsko-hrvatsko-slovenačka IV. 1064-1077.

Belić, A. (1939). Pozorišni jezik. Naš jezik VI 5-6: 129-137.

Bjelaković, I. and M. Marković (2009). Posleakcenatska dužina u govoru Novog Sada. In: Bošnjaković, Ž. (ed.) (2009), 110-128.

Bogdanović, N. and J. Marković (2000). Praktikum iz dijalektologije. Niš: Filozofski fakultet.

Bošnjaković, Ž. (2003). Prozodijski sistem Batovca i njegov odnos prema susednim govorima. Srpski jezik 8/1-2: 315-328.

Bošnjaković, Ž. (ed.) (2009). Govor Novog Sada. Sveska 1: Fonetske osobine. Novi Sad: Filozofski fakultet, Odsek za srpski jezik i lingvistiku.

Bošnjaković, Ž. (2009a). Ispitivanje gradskih govora u Srbiji. In: Bošnjaković, Ž. (ed.) (2009), 47-76.

Bošnjaković, Ž. (2009b). Prenošenje akcenata na proklitiku u govoru Novog Sada. In: Bošnjaković, Ž. (ed.) (2009), 79-109.

Bošnjaković, Ž. (2009c). Fonema / x/ u govoru Novog Sada. In: Bošnjaković, Ž. (ed.) (2009), 268-286.

Bošnjaković, Ž. (2009d). Odnos standardnih i dijalekatskih osobina u govoru učenika nekih banatskih osnovnih škola. Naučni sastanak slavista $u$ Vukove dane 38/1. 341-350.

Bošnjaković, Ž. (2012). Kako odrediti „normu” u govoru i dijalektu. Naučni sastanak slavista u Vukove dane 41/1: 551-560.

Bošnjaković, Ž. (2016). Prilog srpskoj urbanoj dijalektologiji: jezičke napomene uz jedan dorćolski idiolekt. Južnoslovenski filolog 72 3/4: 111-136.

Bošnjaković, Ž. and D. Urošević (2009). Finalne vokalske grupe -ao, -eo, -uo u govoru Novog Sada. In: Bošnjaković, Ž. (ed.) (2009), 246-267.

Bošnjaković, Ž. and D. Radovanović (2009). Fonetske varijacije u govoru izbeglica u Novom Sadu. In: Bošnjaković, Ž. (ed.) (2009), 310-338. 
Bošnjaković, Ž. and I. Knjižar (2012). Sociolingvistički pristup nekim morfofonološkim promenama u govoru Bunjevaca Bajmoka i Tavankuta. Srpski jezik 17: 503-521.

Bugarski, R. (1965). Grad i jezik. Izraz 9/4: 366-375. Sarajevo.

Bugarski, R. (1983). Lingvistika o čoveku. 2nd ed. Beograd: Biblioteka XX vek.

Bugarski, R. (1986). Jezik u društvu. Beograd: Biblioteka XX vek.

Bugarski, R. (2009). Teorijske osnove urbane dijalektologije. In: Bošnjaković, Ž. (ed.) (2009), 13-30.

Bugarski, R. (2015). Selektivna sociolingvistička bibliografija SFRJ/SRJSCG/Srbija 1967-2014. Zemun: Mostart.

Bukumirić, M. (2003). Govori severne Metohije. Srpski dijalektološki zbornik 50.

Chambers, J.K. (2008). Louis Gauchat, Proto-Variationist. Historiographia Linguistica 35: 215-225.

Chambers, J. K. and N. Schilling (2013). The Handbook of Language Variation and Change. $2^{\text {nd }}$ ed. Oxford: Blackwell.

Chambers, J.K. and P. Trudgill (1980). Dialectology. Cambridge: CUP.

Chambers, J.K. and P. Trudgill (1998). Dialectology. 2nd ed. Cambridge: CUP.

Čudomirović, J. (2007). Generacijske razlike u jednom govoru kosovskoresavskog dijalekta i njihov socijalni kontekst. Petničke sveske 62: 169-179.

Ćirić, Lj. (2008). Neke leksičke i gramatičke pojedinosti u pirotskom varoškom govoru. Zbornik Instituta za srpski jezik SANU 1: posvećeno dr Dragu Ćupiću povodom 75-godišnjice života. Beograd: Institut za srpski jezik SANU. 621-628.

Ćupić, D. (1983). Urbanizacija i dijalekat. U: Jeziku savremenoj komunikaciji. Beograd: Centar za marksizam Univerziteta. 53-61.

Dragin, G. (2009). Distribucija posleakcenatskih dužina u jeziku medija. In: Bošnjaković, Ž. (ed.) (2009), 129-140.

Foulkes, P. and G. Docherty (1999). Urban Voices - Overview. In: Paul Foulkes and Gerard Docherty (eds.) Urban Voices: Accent Studies in the British Isles. London: Arnold. 1-24.

Friedman, V. (1997). One Grammar, Three Lexicons: Ideological Overtones and Underpinings in the Balkan Sprachbund. Papers from the 33rd Regional Meeting of the Chicago Linguistic Society. 1-23.

Gal, S. (1989). Lexical Innovation and Loss: Restricted Hungarian. In: Nancy C. Dorian (ed.). Investigating Obsolescence. Studies in Language Contraction and Death. Cambridge: CUP. 313-331. 
Gal, S. (1996). Language Shift. In: Hans Goebl et al. (eds.) Kontaktlinguistik: Ein Internationales Handbuch Zeitgenoessischer Forschung. Berlin: De Gruyter. 586-593

Gauchat, L. (1905) [2008]. Phonetic Unity in the Dialect of a Single Village. Sarah Cummins (trans.). Historiographia Linguistica 35: 227274 . Original: L' unité phonetique dans le patois d' une commune. Festschrift Heinreich Morf: Aus Romanischen Sprachen und Literaturen. Halle: M. Niemeyer. 175-232.

Gudurić, S. (2009). Prilog proučavanju govora Novog Sada: strujni suglasnici [ž] i [š]. In: Bošnjaković, Ž. (ed.) (2009), 287-296.

Ivić, M. (1997). O Vukovom i vukovskom jeziku. $2^{\text {nd }}$ ed. Beograd: Biblioteka XX vek.

Ivić, P. (1983). O nekim referatima. In: Jezik u savremenoj komunikaciji. Beograd: Centar za marksizam Univerziteta. 204-206.

Ivić, P. (1991). Dve akcentološke novosti iz Srema. Izabrani ogledi 3: Iz srpskohrvatske dijalektologije. Niš: Prosveta. 275-292.

Ivić, P. (1994). Dijalektološka proučavanja govora prizrensko-timočke zone. In: P. Ivić et al. (eds.) Govori prizrensko-timočke oblasti i susednih dijalekata. Niš: Filozofski fakultet / Beograd: Institut za srpski jezik SANU. 55-71.

Ivić, P. (1996). Prozodija reči i rečenice u srpskohrvaatskom jeziku. Novi Sad: Izdavačka knjižarnica Zorana Stojanovića.

Ivić, P. (1999). O jeziku, o lingvistima, o piscima. Zbornik Matice srpske za književnost $i$ jezik 47/2: 413-425.

Ivić, P. (2001). Srpski narod i njegov jezik. Novi Sad: Izdavačka knjižarnica Zorana Stojanovića.

Jerković, J. (1992). Srpski govor Bečeja. Zbornik Matice srpske za filologiju i lingvistiku 35/2: 89-98.

Jović, D. (1975). Razvoj jugoslovenskog društva i promene u jeziku. Književnost i jezik 22/1: 26-35.

Jović, D. (1976a). Jezik urbanih sredina. Gledišta 17/7-8: 732-744.

Jović, D. (1976b). Perspektive sociolingvistike u Jugoslaviji. In: Ranko Bugarski et al. (eds.) Jezik u društvenoj sredini. Novi Sad: Društvo za primenjenu lingvistiku Jugoslavije. 21-30.

Jović, D. (1978). Jezičke i društvene osnove nekih promena u govoru urbanih sredina. Gledišta 19: 492-504.

Jović, D. (1979). Sociolingvistički faktori jezičkih promena u župskom govoru. Književnost i jezik 26/2-3: 243-251. 
Jović, D. (1983). Književni jezik i urbani idiom. In: Jezik u savremenoj komunikaciji. Beograd: Centar za marksizam Univerziteta. 34-52.

Jutronić-Tihomirović, D. (1983). Jezik grada. Argumenti 1-2: 196-207.

Jutronić-Tihomirović, D. (1989). Language Change in an Urban Setting. In: M. Radovanović (ed.) Yugoslav General Linguistics. Amsterdam: John Benjamins. 145-162.

Jutronić, D. (2010). Spliski govor, od vapora do trajekta: Po čemu će nas pripoznavat. Split: Naklada Bošković.

Kapović, M. (2004). Jezični utjecaj velikih gradova. Rasprave Instituta za hrvatski jezik i jezikoslovlje 30: 97-105.

Kerswill, P. (2003). Dialect Levelling and Geographical Diffusion in British English. In: D. Britain and J. Cheshire (eds.) Social Dialectology. In honour of Peter Trudgill. Amsterdam: Benjamins. 223-243.

Kerswill, P. (2013). Koineization. In: Chambers, J. K. and Natalie Schilling (eds.) The Handbook of Language Variation and Change. $2^{\text {nd }}$ ed. Oxford: Blackwell. 519-536.

Kristiansen, T. (2001). Two Standards: One for the Media and One for the School. Language Awareness 10/1: 9-24.

Labov, W. (1963). The Social Motivation of a Sound Change. Word 19: 273-309.

Labov, W. (1966). The Social Stratification of English in New York City. Washington D.C.: Center for Applied Linguistics.

Labov, W. (1970). The Study of Language in its Social Context. Studium Generale 23: 30-87.

Labov, W. (1972a). Sociolinguistic Patterns. Philadelphia: University of Pennsylvania Press.

Labov, W. (1972b). Some Principles of Linguistic Methodology. Language in Society 1/1: 97-120.

Labov, W. (1994). Principles of Linguistic Change. Volume 1: Internal Factors. Oxford: Blackwell.

Labov, W. (2001). Principles of Linguistic Change. Volume 2: Social Factors. Oxford: Blackwell.

Labov, W. (2006). The Social Stratification of English in New York City. $2^{\text {nd }}$ ed. Cambridge: CUP.

Labov, W. (2010). Principles of Linguistic Change. Volume 3: Cognitive and Cultural Factors. Oxford: Blackwell. 
Labov, W., S. Ash, and C. Boberg (2006). The Atlas of North American English: Phonetics, Phonology and Sound Change. Berlin/New York: Mouton de Gruyter.

Lass, R. (1997). Historical Linguistics and Language Change. Cambridge: CUP.

Lončar Raičević, A. (2014). Silazni akcenti van prvog sloga (dijalekat standard). In: Putevi i dometi dijalekatske leksikografije. Niš: Filozofski fakultet. 49-57.

Lončar Raičević, A. (2016a). Acoustic Analysis of Postaccentual quantity. Facta Universitatis, Series: Linguistic and Literature 13/2: 135-145.

Lončar Raičević, A. (2016b). Prozodija reči u govoru užičkog kraja. Phd thesis. University of Banja Luka.

Magner, T. (1978). City Dialects in Yugoslavia. In: H. Birnbaum (ed.) American Contributions to the Eighth International Congress of Slavists Vol. 1. Columbus, Ohio: Slavica. 465-482.

Magner, T. (1984). A Century of the Niš Dialect. In: Stolz, Titunik and Doležel (eds.) Language and Literary Theory, Collected Papers in Slavic Philology 5.

Magner, T. and L. Matejka (1971). Word Accent in Modern Serbo-Croatian. University Park, PA / London: Pennsylvania State University Press.

Malkiel, Y. (1984). Revisionist Dialectology and Mainstream Linguistics. Language in Society 13/1: 29-66.

Marinković, J. (1994). Generacijska diferencijacija kao osnov dijalekatskih razlika u govorima Vranjskog Pomoravlja. In: P. Ivić et al. (eds.) Govori prizrensko-timočke oblasti $i$ susednih dijalekata. Niš: Filozofski fakultet / Beograd : Institut za srpski jezik SANU. 225-230.

Marinković, J. and D. Marinković (2012). Savremeni status idioma urbanih sredina u južnoslovenskim jezicima. Зборник на трудови од научниот собир Современи тингвистички истражуваға во македонистика, Институт за македонски јазик „Крсте Мисирков”, Скопје, Јазикот наш денешен, книга 21. 51-58.

Marković, B. (2012). Dunja Jutronić, Spliski govor - od vapora do trajekta. Južnoslovenski filolog LXVIII: 228-232.

Marković, J. (2007). Srpska dijalektologija danas. In: Radoje Simić (ed.). Srpski jezik, književnost i umetnost 1. Kragujevac: Skupština grada. 241-250.

Marković, M. and I. Bjelaković (2009a). Kvantitet dugih posttoničnih vokala u govoru Novog Sada. In: Bošnjaković, Ž. (ed.) (2009), 141-147. 
Marković M. and I. Bjelaković (2009b). Kvantitet naglašenih vokala u govoru Novog Sada. In: Bošnjaković, Ž. (ed.) (2009), 148-158.

Meyerhoff, M. (2011). Introducing Sociolinguistics. $2^{\text {nd }}$ ed. London and New York: Routledge.

Mihajlović, J. (1977). Leskovački govor. Leskovac: Biblioteka narodnog muzeja.

Miletić, B. (1952). Osnovi fonetike srpskog jezika. Beograd: Znanje.

Miloradović, S. (2014). Uzualni standard u urbanim centrima na kosovskoresavskom i prizrensko-timočkom govornom području. In: Zbornik Instituta za srpski jezik SANU 2: Srpski jezik i aktuelna pitanja jezičke politike. 143-150.

Milroy, J. (1992). Linguistic Variation and Change: On the Historical Sociolinguistics of English. Oxford: Blackwell.

Milroy, J. and L. Milroy (1985). Linguistic Change, Social Network, Speaker Innovation. Journal of Linguistics 21: 339-384.

Milroy, J., L. Milroy and S. Hartley (1994). Local and Supra-Local Change in British English - The Case of Glottalisation. English World-Wide 15/1: $1-33$.

Milroy, L. and M. Gordon (2003). Sociolinguistics: Method and Interpretation. Oxford: Blackwell.

Moskovljević, M. (1921). Nekoliko reči o beogradskom govoru. In: Zbornik Filoloških i lingvističkih studija: Aleksandru Beliću povodom 25-godišnjice njegova naučna rada posvećuju njegovi prijatelji i učenici. Beograd: S. B. Cvijanović. 132-140.

Moskovljević, M. (1939/1940). Nove pojave u beogradskom izgovoru. Naš jezik 7/2-3: 69-72.

Pešikan, M. (1991). Akcenat i druga pitanja pravilnog izgovora. In: Ivić et al. (eds) Jezički priručnik. Beograd: RTB. 39-66.

Petrović, D. (1996). Fonetika. In: Milorad Radovanović (ed.) Srpski jezik na kraju veka. Institut za srpski jezik SANU: Službeni glasnik. 87-110.

Petrović, D. (2001). Languages in Contact: Standard Serbian Phonology in an Urban Setting. International Journal of the Sociology of Language 151: 19-40.

Petrović D. and S. Gudurić (2010). Fonologija srpskoga jezika. Beograd: Institut za srpski jezik SANU.

Petrović, T. (2003). Studying the Minority Groups' Identities in the Balkans from the Perspective of Language Ideology. Balcanica 34: 173-188. 
Petrović, T. (2009). Srbi u Beloj Krajini: jezička ideologija u procesu zamene jezika. Beograd: SANU.

Radovanović, M. (2003). Sociolingvistika. $3^{\text {rd }}$ ed. Novi Sad: Izdavačka knjižarnica Zorana Stojanovića.

Radovanović, M. and R. Major (2001). Introduction: On Serbian (socio)linguistics. Serbian Sociolinguistics. International Journal of the Sociology of Language 151: 1-6.

Rajić, Lj. (1980-1981). Jezik i identitet - položaj korisnika dijalekta u procesu standardizacije govora. Godišnjak Saveza društava za primenjenu lingvistiku Jugoslavije 4-5. 373-376.

Rajić, Lj. (2000). Tradicionalno i moderno u srpskoj lingvistici. Lingvističke aktuelnosti 1/2: 111-117.

Remetić, S. (1996). Srpski prizrenski govor. Srpski dijalektološki zbornik 42: 319-614.

Remetić, S. (2013). Sto godina dijalektologije na stranicama Južnoslovenskog filologa. Južnoslovenski filolog 69: 13-32.

Remetić, S. (2016). Srpska dijalektologija danas i sutra. Zbornik Instituta za srpski jezik SANU 3: Srpski jezik i aktuelna pitanja jezičkog planiranja. Beograd: Institut za srpski jezik SANU. 25-33.

Remetić, S. and M. Dragičević (2001). Srpska dijalektologija na početku XXI veka. In: Filozofsko-filološke nauke na početku 21. vijeka 2. Banja Luka: Filozofski fakultet. 143-158.

Savić, S. (1999). Osnovni principi dekskriptcije i selekcije razgovornog jezika: korpus lingvistika. In: Aktuelni problemi gramatike srpskog jezika. Subotica-Beograd: Gradska biblioteka. 85-95.

Sekulić, N. (1981). Zbirka dijalekatskih tekstova iz Vojvodine. Srpski dijalektološki zbornik 27. 107-306.

Simić, R. (1995). Srpska dijalektologija danas. Znamen 1/2: 15-24.

Sredojević, D. (2009a). Eksperimentalno-fonetsko ispitivanje kratkouzlaznog akcenta u novosadskom govoru - tonska komponenta. In: Bošnjaković, Ž. (ed.) (2009), 159-191.

Sredojević, D. (2009b). Akcenat imenica u jeziku voditelja-spikera novosadskih televizijskih stanica. In: Bošnjaković, Ž. (ed.) (2009), 215-234.

Sredojević, D. (2011). Prepoznavanje novosadskog izgovora i stavovi prema njemu. In: Vasić Vera and Gordana Štrbac (eds.). 2011. Govor Novog Sada Sveska 2: Morfosintaksičke, leksičke i pragmatičke osobine. 
Novi Sad : Filozofski fakultet, Odsek za srpski jezik i lingvistiku. 378398.

Sredojević, D. (2015a). Eksperimentalno-fonetsko ispitivanje distinkcija između dugosilaznog i dugouzlaznog akcenta u novosadskom govoru. In: Gudurić, Snežana and Marija Stefanović (eds.) Jezici i kulture u vremenu i prostoru IV/1. Novi Sad: Filozofski fakultet. 335-342.

Sredojević, D. (2015b). Kratkouzlazni akcenat u govoru studenata žurnalistike poreklom iz nečetvoroakcenatskih oblasti. In: Dejan Pralica, Norbert Šinković (eds.) Digitalne medijske tehnologije $i$ društvenoobrazovne promene 5. 235-246.

Sredojević, D. (2017). Fonetsko-fonološki opis akcenata u standardnom srpskom jeziku - od specifičnog ka opštem. Novi Sad: Filozofski fakultet.

Sredojević, D. and Lj. Subotić (2011). Dugouzlazni akcenat u novosadskom govoru: fonetske karakteristike i fonološka interpretacija. Zbornik Matice srpske za filologiju i lingvistiku LIV/2: 108-133.

Stanković, S. (1997). Gradski vlasotinački govor(i) - sociolingvistički procesi. In: O srpskim narodnim govorima: Naučni skup, Despotovac, 21-22. 8. 1996. Dani duhovnog preobraženja IV. 167-179.

Stevanović, M. (1950). Đakovački govor. Srpski dijalektološki zbornik 11.

Stijović, R. (2009). Beograd i književni jezik. Slavistika 13: 343-349.

Stoddart, J. et al. (1999). Sheffield Dialect in the 1990s: Revisiting the Concept of NORMs. In: Foulkes and Docherty (eds.) Urban Voices: Accent Studies in the British Isles. London: Arnold. 72-90.

Stokin, M. (2009). Prozodijske osobine morfoloških kategorija u govoru starog Novog Sada. In: Bošnjaković, Ž. (ed.) (2009), 192-214.

Subotić, Lj., D. Sredojević and I. Bjelaković (2012). Fonetika i fonologija: ortografska i ortoepska norma standardnog srpskog jezika. $2^{\text {nd }}$ ed. Novi Sad: Filozofski fakultet.

Škiljan, D. (1980). Od horizontalne k vertikalnoj stratifikaciji jezika. Naše teme 24/6: 952-962.

Štrbac, G. (2009). Ikavizmi šumadijsko-vojvođanskog tipa u govoru Novog Sada. In: Bošnjaković, Ž. (ed.) (2009), 297-309.

Toma, P. (1998). Govori Niša i okolnih sela. Srpski dijalektološki zbornik XLV.

Tomić, D. (2012a). Govor vranjske dece predškolskog uzrasta i jezički standard. In: Sunčica Denić (ed.) Književnost za decu i njena uloga u vaspitanju i obrazovanju dece predškolskog uzrasta. Vranje: Učiteljski fakultet. 252-273. 
Tomić, D. (2012b). Akcenat govora vranjske dece predškolskog uzrasta. Godišnjak Učiteljskog fakulteta u Vranju 3: 437-449.

Trajković, T. (2015). Govor Preševa. PhD thesis. University of Niš.

Trajković, T. (2017). Niš Speech in the Light of the Newest Sociolinguistic Research. Teme XLI: 41-54.

Trudgill, P. (1974). The Social Differentiation of English in Norwich. Cambridge: CUP.

Trudgill, P. (1978). Introduction: Sociolinguistics and Sociolinguistics. In: Peter Trudgill (ed.). Sociolinguistic Patterns in British English. Baltimore: University Park Press. 1-19.

Trudgill, P. (2000). Sociolinguistics: An Introduction to Language and Society. $4^{\text {th }}$ ed. London: Penguin Books.

Vasić, V. et al. (2007). Percepcija govora Novog Sada i stavovi prema njemu. Primenjena lingvistika 8: 8-21.

Vasić V. and G. Štrbac (eds.) (2011). Govor Novog Sada. Sveska 2: Morfosintaksičke, leksičke i pragmatičke osobine. Novi Sad : Filozofski fakultet, Odsek za srpski jezik i lingvistiku.

Vučković, M. (2009). Savremena dijalektološka istraživanja u srpskoj lingvistici i problematika jezika u kontaktu. Južnoslovenski filolog LXV: 405-423.

Vukomanović, S. (1967). O jednoj akcenatskoj osobini beogradskog govora. Prilozi za književnost i jezik, istoriju i folklor 33/1-2: 43-48.

Vuletić, S. (2014). Eksperimentalno istraživanje sociolingvističkih varijabli u urbanim sredinama srpskog govornog područja. PhD thesis. Faculty of Philology, University of Belgrade.

Weinreich, U., W. Labov and M. Herzog (1968). Empirical Foundations for a Theory of Language Change. In: W. P. Lehmann and Y. Malkiel (eds) Directions for Historical Linguistics, Austin: University of Texas Press, 95-195.

Williams, R. (1973). The Country and the City. New York: Oxford University Press.

Wolfram, W. (2006). Variation in Language: Overview. In: Keith Brown (ed.). Encyclopedia of Languages and Linguistics. $2^{\text {nd }}$ ed. Oxford: Elsevier. 333-340.

Wolfram, W. and N. Schilling (2015). American English. 3rd ed. Malden/ Oxford: Wiley-Blackwell.

Received: 1 October 2017

Accepted for publication: 31 January 2018 
Андреј Бјелаковић

\title{
КАМО ВАРИЈАЦИОНИСТИЧКА СОЦИОЛИНГВИСТИКА У СРБИЈИ?
}

\begin{abstract}
Сажетак
Мало се променило од 1965. и првобитног позива Р. Бугарског за изучавање градског говора у Југославији (и његовог потоњег извештавања о рађању и развитку варијационистичке социолингвистике). Ми и даље не знамо како већина Срба говори, те који је обим стилистичке и друштвене варијације у градовима српског говорног подручја. У раду ћемо покушати да покажемо како социолингвистике у ужем смислу у Србији углавном није било; покушаћемо затим да понудимо неке од разлога за такво стање ствари; такође ћемо и истаћи оно мало што јесте урађено на пољу урбане дијалектологије и варијационистичке социолингвистике.
\end{abstract}

Кључне речи: социолингвистика, српски, дијалектологија 